\title{
PENERAPAN ALGORITMA C4.5 UNTUK KLASIFIKASI PENENTUAN PENERIMAAN BANTUAN LANGSUNG DI DESA CIOMAS \\ Irmayansyah $^{1 *}$, Aulia Arief Firdaus ${ }^{2}$ \\ ${ }^{1}$ Irmayansyah/Sistem Informasi /Magister Komputer Sistem Informasi STIKOM BINANIAGA . \\ Email: irma@stikombinaniaga.ac.id \\ ${ }^{2}$ Aulia Arief Firdaus /Sistem Informasi / \\ STIKOM BINANIAGA
}

\begin{abstract}
In the implementation of aid programs for the poor, there are still problems in the implementation of the lack of accurate beneficiaries because the data received are not in accordance with the conditions of the population in different areas with the method of Algoritama c4.5 will be classified as beneficiaries for the poor people based on on the population economic census data using 10 determinant variables that then implemented in an information system based on android webview as output from the system in the form of a list of beneficiaries who are eligible to receive to test the research beneficiaries conducted questionnaires on users where the results of the questionnaire showed the overall percentage of eligibility from all aspects of penilaian that is $74,9 \%$ which is classified as feasible.
\end{abstract}

Keywords: c4.5 algorithm, help program, classification, android webview

\begin{abstract}
ABSTRAK
Dalam penyelenggaran program bantuan pemberian bantuan kepada penduduk tidak mampu masih terdapat masalah pada pelaksanaannya yaitu kurang akuratnya penerima bantuan karena data yang diterima tidak sesuai dengan keadaan penduduk yang ada di berbagai wilayah dengan metode Algoritama c4.5 akan diklasifikasikan yang penerima bantuan bagi penduduk tidak mampu berdasarkan pada data sensus ekonomi penduduk dengan menggunakan 10 variabel penentu yang kemudiam di implementasikan pada sebuah sistem informasi berbasis android webview adapun keluaran dari sistem tersebut berupa daftar penerima bantuan yang berhak menerima untuk menguji penelitian penerima bantuan dilakukan angket pada pengguna dimana hasil angket tersebut menunjukan presentase kelayakan keseluruhan dari semua aspek peniliaian yaitu 74,9\% yang tergolong layak.
\end{abstract}

Kata Kunci: algoritma c4.5,program bantuan,klasifikasi,android webview

\section{PENDAHULUAN}

\section{Latar Belakang}

Dampak sosial yang terjadi akibat masalah dari pertumbuhan penduduk antara lain adalah kemiskinan, karena banyaknya penduduk, lapangan pekerjaan terbatas, akibatnya banyak yang menganggur. Dalam peraturan pemerintah tentang pelaksanaan upaya penganan fakir miskin melalui pendekatan wilayah yaitu Peraturan Pemerintah Nomor 63 Tahun 2013 tentang Pelaksanaan Upaya Penanganan Fakir Miskin Melalui Pendekatan Wilayah (Lembaran Negara Republik Indonesia Tahun 2013 Nomor 157), Tambahan Lembaran Negara Republik Indonesia 
Nomor 5449),Pasal 2 (1) Pemerintah dan Pemerintah Daerah bertanggungjawab terhadap pelaksanaan Penanganan Fakir Miskin. (2) Masyarakat berperan serta dalam pelaksanaan Penanganan Fakir Miskin yang dilaksanakan sesuai dengan ketentuan peraturan perundangundangan.

Untuk mengatasi kemiskinan tersebut dengan mengacu pada peraturan tersebut pemerintah telah menyelanggarakan program bantuan kemiskinan penduduk seperti BLSM(bantuan langsung sementara), program PKH (program keluarga harapan),KIS (kartu indonesia sehat) dan RASKIN (beras miskin) untuk mengatasi masalah kemiskinan namun dalam penyelenggaran program tersebut masih terdapat masalah pada pelaksanaannya yaitu kurang akuratnya penerima bantuan tersebut karena data yang diterima tidak sesuai dengan keadaan penduduk yang ada di berbagai wilayah.

Kota bogor adalah salah satu wilayah yang berada di provinsi jawa barat Menurut data statistik kota bogor jumlah penduduk kota bogor yaitu sebesar 1.030 .720 jiwa tahun 2014 dimana terbagi dalam beberapa wilayah seperti Bogor selatan 194.179 jiwa,Bogor timur 101. 984 jiwa,Bogor utara 186.098 jiwa,Bogor tengah 104.120 jiwa,Bogor barat 228.860 jiwa dan Tanah sereal 215.479 jiwa dimana Bogor barat memiliki jumlah penduduk terbanyak dan itu bukan tidak mungkin akan meimbulkan masalah yaitu dari segi ekonomi dan daya beli pendudukdata tersebut bisa berubah seiring berkembangnya waktu karena fenomena yang terjadi di penduduk sulit diprediksi seperti angka kelahiran, kematian, kepindahan dan kedatangan penduduk harus selalu diperbaharui hingga data menjadi akurat di berbagai wilayah kota bogor(https://bogorkota.bps.go.id/linkTabelStatis/view/id/15)

Kecamatan ciomas merupakan salah satu wilayah yang berada di kota bogor barat yang,memiliki jumlah RW (Rukun Warga) sebanyak 12 RW dimana di tiap RW tersebut memliki beberapa RT (Rukun Tetangga) dengan jumlah penduduk kurang lebih 13.000 jiwa.Data statistik tahun 2014 dari badan statistik pusat bogor,menyebutkan bahwa wilayah bogor barat memiliki jumlah penduduk terbanyak di antara beberapa wilayah kota bogor.

Beberapa program bantuan pemerintah kepada penduduk tidak mampu yang terdapat di desa ciomas seperti PKH (program keluarga harapan),KIS (kartu indonesia sehat) dan RASKIN (Beras miskin),PKH adalah sebuah program bantuan yang diterima oleh keluarga yang tidak mampu dimana data penerimaan untuk penentuan berdasarkan data sensus ekonomi keluarga sedangkan KIS adalah program pemerintah tentang bantuan kesehatan bagi penduduk tidak mampu dan RASKIN adalah program pemerintah bantuan tentang bahan pokok bagi kehidupan penduduk tidak mampu dimana ketiga program bantuan tersebut berhubungan dengan kondisi ekonomi penduduk

Dalam pelaksanaan pemberian bantuan tersebut kantor desa ciomas menggunakan data rekomendasi dari masing-masing RukunTetangga (RT) hal tersebut disebabkan karena kantor 
desa tidak memiliki informasi yang lengkap tentang golongan penduduk mampu dan tidak mampu,seharusnya data yang digunakan untuk menentukan penerima bantuan langsung adalah data sensus ekonomi, data tersebut tidak dipakai karena terdapat keterbatasan dalam pengolahan data Hal tersebut berdampak pada keakuratan data penerima bantuan langsung.

Algoritama c4.5 ditujukan dengan teknik klasifikasi yang merupakan salah satu teknik dari data mining untuk menganalisa suatu memprediksi penerima bantuan bagi penduduk tidak mampu berdasarkan pada data sensus ekonomi penduduk. Menurut Dennis Aprilla C,Donny Aji Baskoro, Lia Ambarwati,I Wayan Simri Wicaksana (2013,p:31) Algoritma C4.5 dapat menangani data numerik dan diskret. Algoritma C.45 menggunakan rasio perolehan (gain ratio). Sebelum menghitung rasio perolehan, perlu dilakukan perhitungan nilai informasi dalam satuan bits dari suatu kumpulan objek, yaitu dengan menggunakan konsep entropi.

Di dalam penelitian ini akan menggali hubungan yang tersembunyi dengan menggunakan algoritma c4.5 dimana data training yang sudah ada akan menghasilkan aturan dan klasifikasi penduduk yang tergolong mampu dan tidak mampu untuk menemukan model dari training set yang membedakan atrribut ke dalam kategori kelas yang sesuai kemudian model tersebut digunakan untuk mengklasifikasi attribut yang kelasnya belum diketahui sebelumnya.

\section{Rumusan Masalah}

Dalam pemberian bantuan langsung kepada penduduk di desa ciomas masih terdapat ketidaktepatan dalam penerimaan bantuan langsung, hal tersebut disebabkan karena penentuan penerima bantuan langsung dilakukan atas rekomendasi perangkat desa yaitu RT dengan peyeleksian hanya berdasarkan pada jenis pekerjaan penduduk,seharusnya penyeleksian tersebut dapat menggunakan data sensus ekonomi penduduk yang memiliki variabel lebih detail, akibat dari cara penyeleksian yang dilakukan selama ini oleh desa ciomas terdapat keluhan dari penduduk dikarenakan penduduk yang tergolong tidak mampu tidak menerima bantuan tersebut. Hal tersebut bukan tidak mungkin akan menimbulkan masalah sosial apabila ketidaktepatan penerima bantuan tersebut terjadi secara berulang,.

Untuk mengatasi hal tersebut maka diperlukan sebuah sistem yang dapat mengolah data menjadi informasi yang dapat menentukan golongan penduduk mampu dan tidak mampu berdasarkan wilayah yang berada di desa ciomas sehingga dapat menjadi rekomendasi bagi kepala desa dalam menentukan penduduk penerima bantuan langsung .Sistem yang akan dikembangkan dalam penelitian ini menerapkan sebuah metode algoritma c4.5 berbasis web dengan menggunakan beberapa variabel untuk menentukan penerima bantuan langsung sesuai dengan data yang berada pada data sensus ekonomi penduduk seperti 1. Jenis atap rumah, 2. Jenis pekerjaan, 3. Jenis dinding rumah terluas, 4. Jenis lantai rumah terluas, 5. Sumber penerangan utama, 6. Sumber air minum, 7. Bahan bakar utama untuk memasak, 8. Fasilitas tempat buang air besar, 9. Status kepemilikan rumah, 10. Luas rumah. 
Berdasarkan uraian diatas, maka dapat diidentifikasi masalah dalam penerimaan bantuan langsung penduduk yaitu:

a. Ketidaktepatan penentuan dalam penerima bantuan.

b. Tidak efektifnya sistem dalam dalam menentukan keputusan / penentuan hasil

\section{METODE PENGEMBANGAN}

Dalam penelitian ini metode yang digunakan adalah eksperimen, artinya bahwa penelitian yang dilakukan untuk melakukan uji coba terhadap permasalahan tertentu dengan penggunaan teori tertentu sehingga didapatkan hasil pengujian yang tepat antara permasalahan yang diambil dengan teori yang digunakan.Model pengembangan yang digunakan dalam penelitian ini adalah pemrograman ekstrem (Extreme Programming [XP]).

\section{PROSEDUR PENGEMBANGAN}

Prosedur pengembangan merupakan langkah-langkah dari proses pengembangan yang dilakukan. Prosedur pengembangan dalam penelitian yang akan dilakukan adalah

1. Analisa Kebutuhan, yaitu pengumpulan data-data yang diperlukan untuk digunakan sebagai dasar dari pengembangan sistem penerima bantuan.

2. Desain Produk, yaitu pendefinisian dari kebutuhan-kebutuhan fungsional dan persiapan untuk rancang bangun implementasi; menggambarkan bagaimana sistem penerima bantuan dibentuk

3. Implementasi Produk, yaitu penerapan sistem yang sudah sesuai dengan kebutuhan untuk digunakan.

4. Pengujian ahli,yaitu produk awal yang di uji coba kepada ahli kependudukan.

5. Revisi produk 1,yaitu memperbaiki produk awal yang telah di uji coba kepada ahli kependudukan.

6. Uji Kelompok,yaitu menguji coba produk yang telah diperbaiki pada tahap awal uji coba 1 kepada pengguna

7. Revisi produk 2.yaitu memperbaiki produk yang telah di uji coba pada tahap ke 2

8. Produk akhir,yaitu produk yang telah di revisi melalui tahap uji coba ahli kependudukan dan ahli pengguna lalu Kritik dan saran dari responden menjadi dasar dari perbaikan ini. Setelah perbaikan ulang jadilah produk akhir

\section{Subjek Uji Coba}

Subjek uji coba produk ini adalah 32 RT di wilayah desa ciomas dan 1 orang staf bagian kependudukan desa ciomas. Penentuan responden RT sebanyak 32 orang ditentukan berdasarkan hasil perhitungan sample dengan menggunakan rumus slovin dengan persen kelonggaran ketidaktelitian ditetapkan sebesar $10 \%$. 


\section{Teknik Analisis Data}

Data yang diperoleh melalui instrumen penilaian pada saat uji coba dianalisis dengan menggunakan statistik deskriptif kualitatif. Analisis ini dimaksudkan untuk menggambarkan karakteristik data pada masing-masing variabel. Dengan cara ini diharapkan akan mempermudah memahami data untuk proses analisis selanjutnya. Hasil analisis data digunakan sebagai dasar untuk merevisi produk penerima bantuan yang dikembangkan. Teknik analisis data yang dilakukan adalah menggunakan teknik analisis deskriptif kualitatif yaitu memaparkan hasil pengembangan produk yang berupa penerimaan bantuan berbasis komputer, menguji tingkat validasi dan kelayakan produk untuk diimplementasikan yang terkumpul diproses dengan cara dijumlahkan, dibandingkan dengan jumlah yang diharapkan dan diperoleh persentase (Arikunto, 1996: 244). Hasil Presentase digunakan untuk memberikan jawaban atas kelayakan dari aspek-aspek yang diteliti. Menurut Arikunto (2009: 44) pembagian kategori kelayakan ada lima. Skala ini memperhatikan rentang dari bilangan presentase. Nilai maksimal yang diharapkan adalah $100 \%$ dan minimum 0\%. Pembagian rentang kategori kelayakan menurut arikunto (2009: 44) dapat dilihat pada tabel berikut :

\section{Tabel 1 Kategori kelayakan menurut Arikunto}

\begin{tabular}{|c|c|}
\hline Presentase Pencapaian & Interpretasi \\
\hline$<21 \%$ & Sangat Tidak Layak \\
\hline $21 \%-40 \%$ & Tidak Layak \\
\hline $41 \%-60 \%$ & Cukup layak \\
\hline $61 \%-80 \%$ & Layak \\
\hline $81 \%-100 \%$ & Sangat Layak \\
\hline
\end{tabular}

Sumber: Arikunto (2009: 44)

Pada tabel 2 kategori kelayakan disebutkan presentase pencapaian, skala nilai, dan interprestasi. Untuk mengetahui kelayakan digunakan tabel 2 tersebut sebagai acuan penilaian data yang dihasilkan dari validasi ahli kependudukan dan pengguna.

\section{HASIL DAN PEMBAHASAN}

\section{Hasil}

\section{Perencanaan}

Dalam perencaan awal penelitian ini terbagi menjadi 3 yaitu Analisis kebutuhan, pemodelan proses dan pemodelan logika untuk menentukan apa saja yang diperlukan dalam melaksanakan penelitian ini. 


\section{a. Analisis Kebutuhan}

Tahap ini dilakukan dengan cara pengumpulan kebutuhan yang dilanjutkan dengan analisis kebutuhan untuk memperoleh hasil analisis yang akan diterapkan dalam pengembangan aplikasi penerima bantuan langsung, analisis kebutuhan dilakukan dengan cara :

\section{1) Pengumpulan dokumen}

Pengumpulan dokumen dilakukan dalam rangka mengidentifikasi permasalahan dan kebutuhan data yang nantinya diperlukan dalam pengembangan adapun dokumen yang dikumpulkan adalah :

a) Data sensus ekonomi penduduk desa ciomas tahun 2015 yaitu data yang berupa lembar survei keadaan ekonomi penduduk yang dilakukan oleh dinas terkait.informasi yang diperlukan pada dokumen tersebut adalah pengambilan informasi tentang attribut ekonomi penduduk yang akan digunakan untuk di analisa pada pengembangan ini.

b) Penerima bantuan raskin 2016 yaitu data penduduk yang menerima bantuan raskin yang tergolong tidak mampu serta informasi yang diperlukan pada dokumen tersebut adalah pengambilan informasi untuk identifikasi masalah yang selama ini terjadi.

\section{2) Wawancara}

Wawancara dilakukan dengan perangkat desa yaitu bidang kesra (kesejahteraan penduduk) yang menangani pelayanan pemberian bantuan langsung di desa ciomas adapun hasil wawancara adalah :

a) Kriteria yaitu faktor penentu penerima bantuan yang selama ini dilakukan oleh desa ciomas,kriteria yang digunakan adalah jenis pekerjaan penduduk yang disurvei oleh RT yang berada di desa ciomas.

\section{b) Proses pemberian bantuan langsung di desa ciomas}

Berdasarkan pada informasi yang di dapat dalam pemberian bantuan langsung di desa ciomas yang selama ini dilakukan oleh desa ciomas yaitu data penduduk yang ada di ciomas di survei oleh setiap RT berdasarkan pekerjaan yang berada di daerah ciomas lalu setiap RT memberikan data penerima bantuan kepada petugas yang berada di desa ciomas setelah data penerima bantuan tersebut diterima lalu pihak desa mengirimkan bantuan tersebut kepada setiap RT yang akan diberikan kepada penduduk tidak mampu di wilayah RT tersebut

\section{b. Hasil Analisis}

Pada tahapan ini adalah hasil analisa untuk solusi yang ditawarkan guna mengatasi kelemahan pada sistem lama adapun hasil analisa tersebut yaitu : 


\section{1) Proses pemberian bantuan yang akan dikembangkan}

Berdasarkan pada analisis kelemahan sistem lama yaitu pihak desa tidak dapat memonitor penduduk penerima bantuan tersebut layak atau tidak berdasarkan data ekonomi dan tidak mengetahui bantuan tersebut sudah diterima atau tidak oleh penduduk yang layak menerima bantuan serta memerlukan waktu yang lama untuk menentukan penerima bantuan dijelaskan pada gambar 1 .

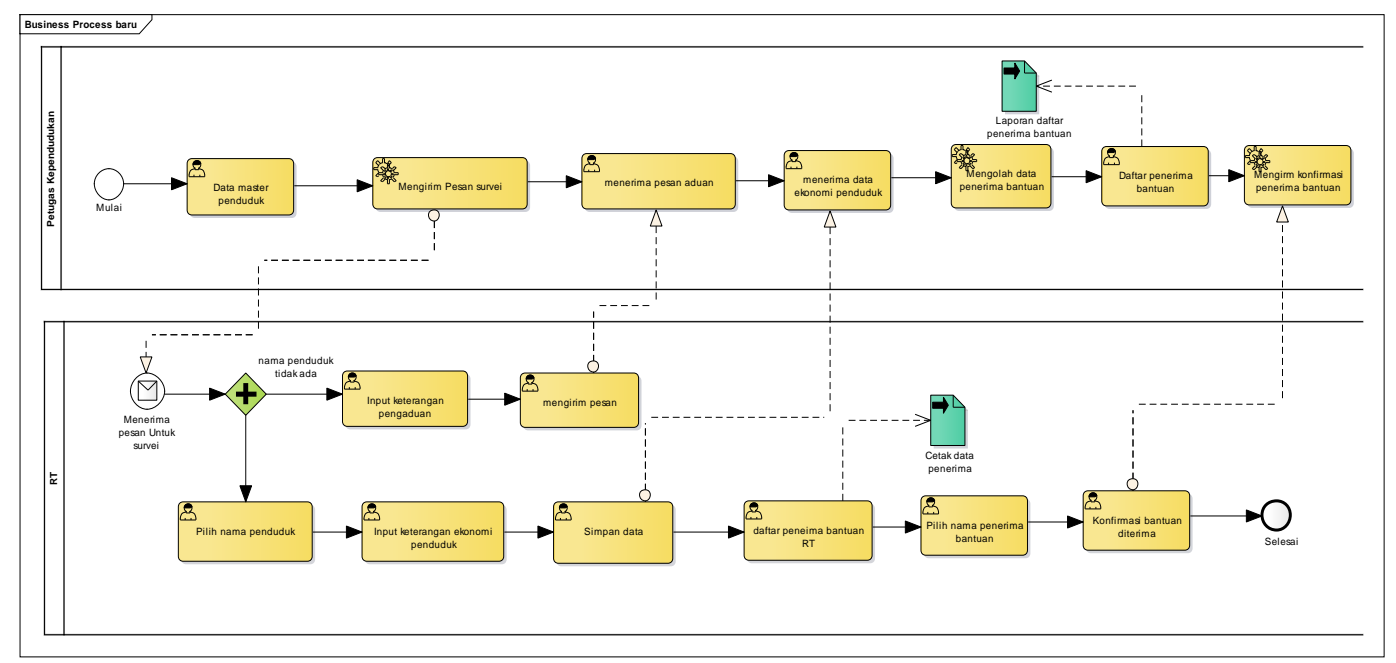

Gambar 1 proses bisnis baru

Pada gambar 1 proses bisnis baru petugas kependudukan mengirim pesan kepada RT untuk melakukan pembaruan data ekonomi penduduk dan mengisi form kategori ekonomi yang tersedia di dalam sistem apabila nama penduduk tidak tersedia maka RT bisa mengirim pesan aduan dan memberikan keterangan kepada pihak kependudukan di desa ciomas dan jika nama penduduk masih berada di wilayah RT tersebut RT mengisi form ekonomi penduduk yang nanti akan diolah oleh sistem dengan algoritma c4.5 menjadi daftar penerima bantuan setelah itu dafar penerima bantuan tersebut diterima oleh RT apabila bantuan sudah tersalurkan kepada nama penduduk yang berada di daftar penerima tersebut RT konfirmasi bahwa bantuan telah diterima oleh penduduk tersebut.

\section{2) Use case}

Pemodelan objek pada sistem yang dikembangkan ini dijelaskan dalam bentuk diagram use case berdasarkan pada proses bantuan langsung pada sistem yang akan dikembangkan untuk memodelkan serta mengorganisasi pada sistem sehingga mendapatkan keluaran sistem sesuai dengan yang diharapkan dan dibutuhan.

Pada gambar 2 use case dapat dijelaskan terdapat 2 aktor pengguna dalam sistem penerima bantuan yaitu petugas kependudukan dan RT,petugas kependudukan 
untuk akses kedalam sistem diharuskan untuk login terlebih dahulu, setelah itu dapat mengakses data master penduduk di dalam form, dalam data master penduduk terdapat input update dan import data, lalu form daftar pengguna digunakan untuk membuat daftar pengguna yang dapat mengakses sistem,pesan digunakan untuk menerima keterangan aduan dari pengguna serta memberikan informasi tentang bantuan apabila ada aduan,data ekonomi penduduk digunakan untuk melakukan filter penerima bantuan dengan algoritma c 4.5 berdasarkan pada data tersebut dan logout digunakan untuk keluar dari sistem.

RT atau pengguna diharuskan login dengan data pengguna yang terdaftar pada sistem ,kemudian data penduduk dapat digunakan untuk input keterangan ekonomi penduduk terbaru apabila nama penduduk sudah tidak ada di wilayah RT tersebut RT dapat mengirim pesan aduan pada petugas kependudukan,daftar penerima bantuan digunakan untuk melihat penerima bantuan yang telah diolah oleh sistem dan RT diharuskan konfirmasi nama penerima bantuan.

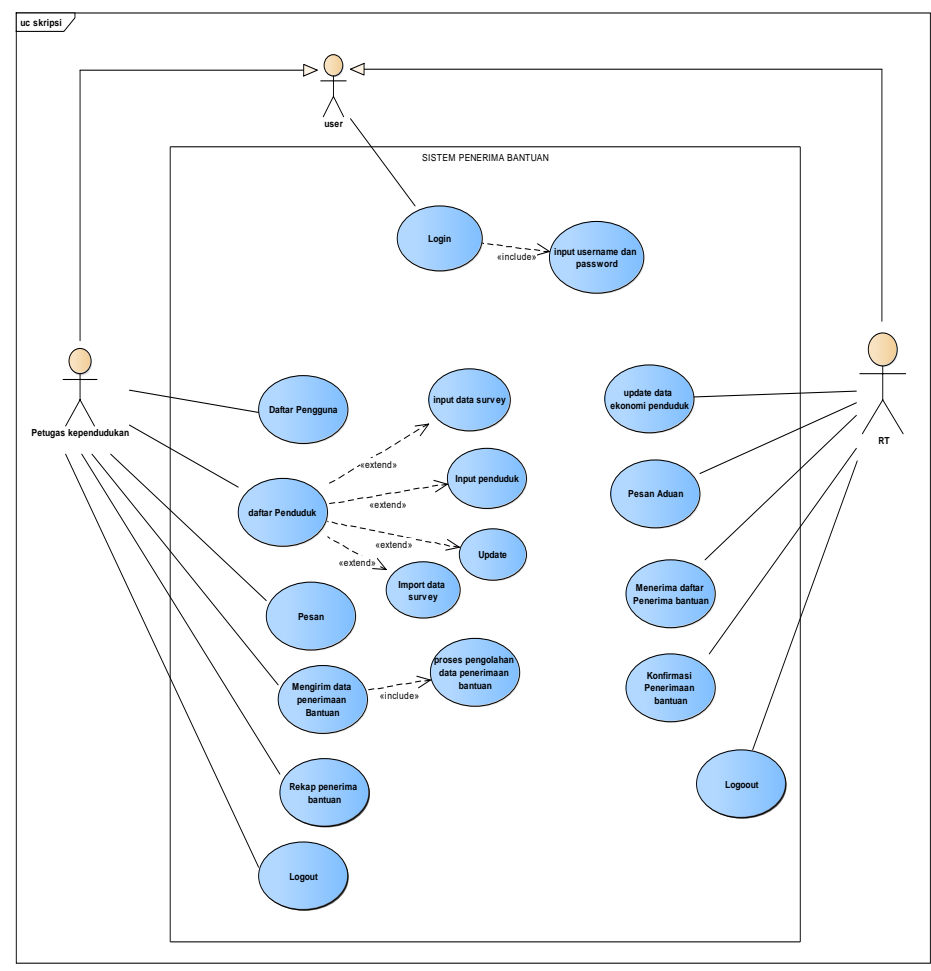

Gambar 2 Use Case

\section{3) Interface}

\section{a. Form input daftar penduduk admin}

Form input daftar penduduk digunakan untuk menambah data penduduk yang tidak tersedia di dalam sistem dimana data yang di inputkan akan tersimpan pada database, form input penduduk hanya dapat di akses oleh admin sistem. 


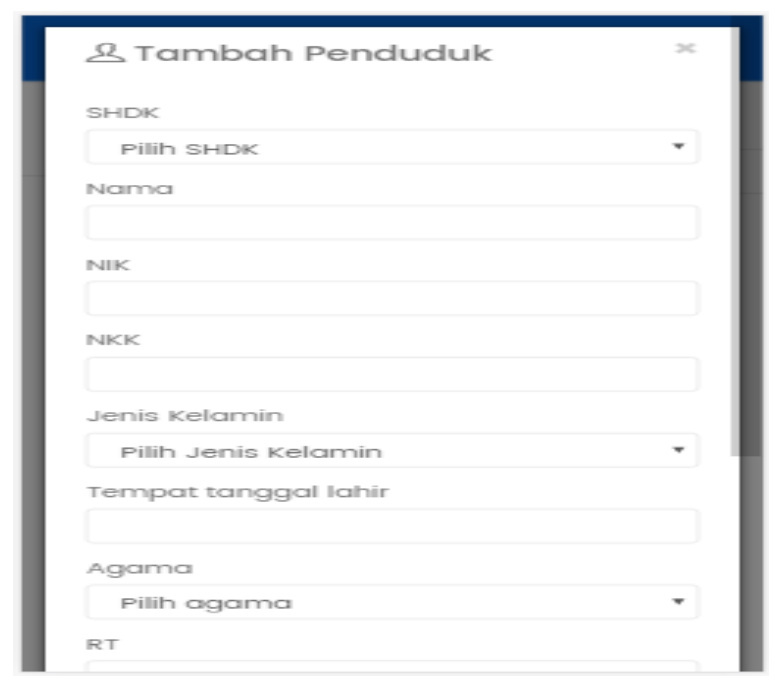

Gambar 3 Form Input Data Penduduk

\section{b. Form data survey}

Form data survey digunakan untuk mengisi keterangan ekonomi penduduk yang akan di uji oleh algoritma c4.5.

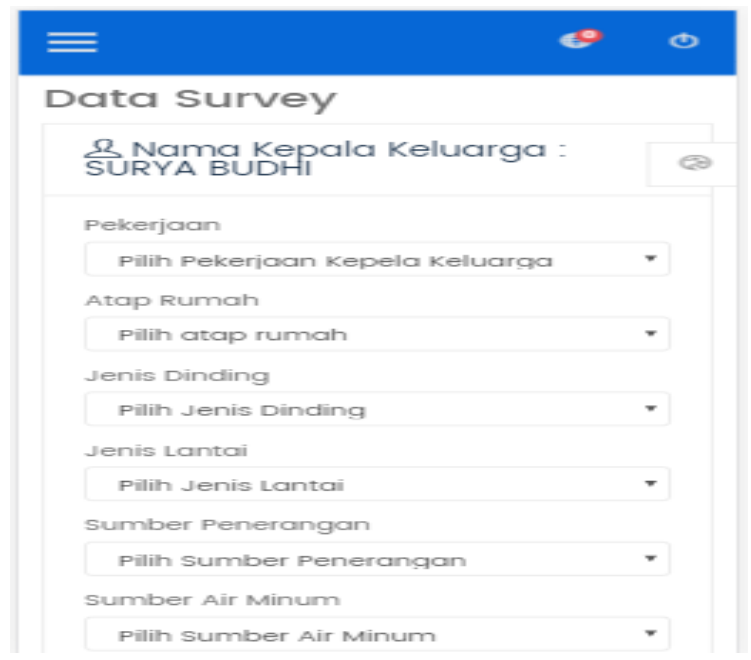

Gambar 4 Form Data Survey

\section{c. Hasil Perhitungan c4.5}

Halaman perhitungan c4.5 yaitu halaman yang terdapat informasi hasil perhitugan $c 4.5$ yang digunakan untuk pembentukan akar keputusan c4.5. 


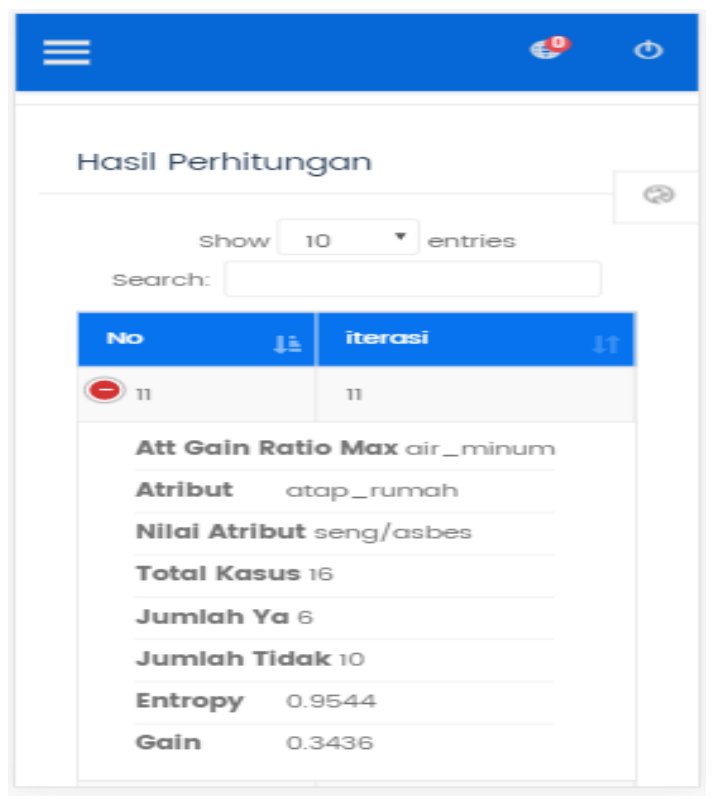

\section{Gambar 5 Form Data Survey}

\section{d. Laporan Penerima bantuan}

Laporan data penerima bantuan yang telah diolah oleh sistem sebagai output dari sistem bantuan langsung ini.

\begin{tabular}{l}
$\quad$ Rekap Penerimaan Bantuan 2017 \\
\hline DESA CIOMAS \\
KECAMATAN CIOMAS \\
KABUPATEN BOGOR \\
BULAN/TAHUN : 01 November 2017 - 30 December 2017
\end{tabular}

\begin{tabular}{|c|c|c|c|c|}
\hline No & Nama & RT $\mathbf{R W}$ & \begin{tabular}{|l|} 
Status Konfirmasi \\
\end{tabular} & Tanggal Keputusan Bantuan \\
\hline 1 & IRMAWAN & \begin{tabular}{|l|l|}
04 & 04 \\
\end{tabular} & sudah & 16 November 2017 \\
\hline 2 & SURYA BUDHI & \begin{tabular}{l|l|}
04 & 04 \\
\end{tabular} & sudah & 16 November 2017 \\
\hline 3 & VITO ARIA BRATA & \begin{tabular}{l|l|l}
04 & 04 \\
\end{tabular} & belum & 16 November 2017 \\
\hline 4 & YAHYA & \begin{tabular}{l|l|l}
04 & 04 \\
\end{tabular} & belum & 16 November 2017 \\
\hline 5 & YUSUF NURRAHMAT & \begin{tabular}{|l|l|l|}
04 & 04 \\
\end{tabular} & belum & 16 November 2017 \\
\hline 6 & ZULFIKAR MALIS & \begin{tabular}{|l|l}
04 & 04 \\
\end{tabular} & belum & 16 November 2017 \\
\hline 7 & TOPIK HIDAYAT & \begin{tabular}{l|l}
04 & 04 \\
\end{tabular} & belum & 16 November 2017 \\
\hline 8 & SULAIMAN & \begin{tabular}{|l|l}
04 & 04 \\
\end{tabular} & belum & 16 November 2017 \\
\hline 9 & KOMARUDIN & \begin{tabular}{|l|l|}
04 & 04 \\
\end{tabular} & belum & 16 November 2017 \\
\hline 10 & IRMAWAN & \begin{tabular}{|l|l|}
04 & 04 \\
\end{tabular} & sudah & 20 November 2017 \\
\hline 11 & SURYA BUDHI & \begin{tabular}{|l|l|}
04 & 04 \\
\end{tabular} & sudah & 20 November 2017 \\
\hline 12 & VITO ARIA BRATA & \begin{tabular}{|l|l|}
04 & 04 \\
\end{tabular} & belum & 20 November 2017 \\
\hline 13 & YAHYA & \begin{tabular}{|l|l}
04 & 04 \\
\end{tabular} & belum & 20 November 2017 \\
\hline 14 & YUSUF NURRAHMAT & \begin{tabular}{|l|l|l|}
04 & 04 \\
\end{tabular} & belum & 20 November 2017 \\
\hline 15 & ZULFIKAR MALIS & \begin{tabular}{|l|l|l}
04 & 04 \\
\end{tabular} & belum & 20 November 2017 \\
\hline 16 & TOPIK HIDAYAT & \begin{tabular}{l|l}
04 & 04 \\
\end{tabular} & belum & 20 November 2017 \\
\hline 17 & SULAIMAN & \begin{tabular}{|l|l|}
04 & 04 \\
\end{tabular} & belum & 20 November 2017 \\
\hline 18 & KOMARUDIN & \begin{tabular}{|l|l|}
04 & 04
\end{tabular} & belum & 20 November 2017 \\
\hline & & & & $\begin{array}{l}\text { Ciomas,14 Desember } 2017 \\
\text { Kepala Desa Ciomas }\end{array}$ \\
\hline
\end{tabular}

Gambar 6 Laporan penerima bantuan

\section{Analisis Data}

Hasil presentase digunakan sebagai jawaban atas kelayakan dari aspek-aspek yang diteliti dengan hasil angket dijumlahkan berdasarkan point jawaban lalu dibandingkan dengan 
jumlah yang diharapkan untuk memperoleh presentase, berikut hasil kelayakan presentase dari produk yang dikembangkan

Tabel 3 presentase kelayakan

\begin{tabular}{|c|c|c|c|c|}
\hline No & Aspek Penilaian & $\begin{array}{c}\text { Skor } \\
\text { Observasi }\end{array}$ & $\begin{array}{c}\text { Skor yang } \\
\text { diharapkan }\end{array}$ & Kelayakan \\
\hline 1 & Kualitas Informasi & 347 & 440 & $78,8 \%$ \\
\hline 2 & Kualitas Sistem & 419 & 550 & $76,1 \%$ \\
\hline 3 & Kualitas layanan & 244 & 330 & $73,9 \%$ \\
\hline 4 & Penggunaan & 149 & 220 & $67,7 \%$ \\
\hline 5 & Kepuasan Pengguna & 155 & 220 & $70,4 \%$ \\
\hline 6 & Keuntungan bersih & 251 & 330 & $76 \%$ \\
\hline \multicolumn{2}{|c|}{ Jumlah } & 1565 & 2090 & $74,9 \%$ \\
\hline
\end{tabular}

Dari hasil pengumpulan data diketahui bahwa rata - rata perolehan skor pada hasil sebaran angket ialah 74,9\%.dimana perolehan skor tertinggi yaitu $76 \%$ terdapat pada keuntungan bersih dan skor paling rendah penggunaan yaitu $67 \%$.berdasarkan presentase kelayakan maka dapat disimpulkan bahwa sistem layak merujuk pada tabel kelayakan yang di kemukanan arikunto.

\section{SIMPULAN DAN SARAN}

Berdasarkan pada hasil penelitian yang telah dilakukan dapat ditarik beberapa kesimpulan sebagai berikut :

1. Penambahan varibel filter penentu bantuan sesuai data ekonomi penduduk dapat di implementasikan ke dalam sistem, sehingga terbentuk aturan baru bagi penentuan penerima bantuan di desa ciomas .

2. Sistem dapat memudahkan penentuan bantuan kepada penduduk. Berdasarkan data yang diperoleh melalui angket diperoleh nilai presentase kelayakan yaitu 74,9\% . berdasarkan presentase kelayakan maka dapat disimpulkan bahwa sistem yang dikembangkan layak merujuk pada tabel kelayakan yang di kemukanan arikunto.

Saran dalam penelitian tentan sistem penerima bantuan bantuan langsung sebagai berikut :

1. Untuk penelitian selanjutnya dapat menggunakan metode lain untuk mengklasifikasikan penerima bantuan seperti naive bayes dan kmeans

2. Sistem yang dikembangkan berbentuk android web view untuk menambahkan kecepatan akses disarankan menggunakan native android dan menambahkan push notifikasi pada sistem. 
Jurnal Ilmiah Teknologi - Informasi dan Sains (TeknolS)

Volume 8 Nomor 1 Bulan Mei 2018 Hal. 17-28

p-ISSN : 2087-3891 dan e-ISSN : 2597-8918

\section{DAFTAR RUJUKAN}

Arikunto, S. 2006. Prosedur Penelitian Suatu Pendekatan Praktik, Jakarta : Rineka Cipta

C, Dennis Aprilla. 2013. "Belajar Data Mining dengan RapidMiner." Innovation

and Knowledge Management in Business Globalization: Theory \&

Practice, Vols 1 and 2 (4): 1-5. doi:10.1007/s13398-014-0173-7.2

https://bogorkota.bps.go.id/linkTabelStatis/view/id/15

kemsos.go.id. (2014). Pembahasan Panduan Teknis Verifikasi dan Validasi Data

PBI Jamkes.

Peraturan Pemerintah Nomor 63 Tahun 2013 tentang Pelaksanaan Upaya

Penanganan Fakir Miskin Melalui Pendekatan Wilayah (Lembaran

Negara Republik Indonesia Tahun 2013 Nomor 157) 